\title{
Impact of Planting Distances and Sowing Dates on Yield Attributing Traits of Okra [Abelmoschus esculentus (L.) Moench] cv. Kashi Pragati
}

\author{
I.D. Bake, B.K. Singh, A.K. Singh, D.P. Moharana* and A.K. Maurya \\ Department of Horticulture, Institute of Agricultural Sciences, Banaras Hindu \\ University, Varanasi, Uttar Pradesh-221 005 \\ *Corresponding author
}

\begin{abstract}
A B S T R A C T

\begin{tabular}{|c|c|}
\hline Keywords & $\begin{array}{l}\text { Optimum plant density along with appropriate sowing date plays a significant role } \\
\text { with respect to the growth, yield, and quality in okra. The present experiment was }\end{array}$ \\
\hline $\begin{array}{l}\text { Okra, Spacings, } \\
\text { Sowing dates, } \\
\text { Interaction effect, } \\
\text { Yield, Quality } \\
\text { attributes. }\end{array}$ & $\begin{array}{l}\text { conducted to assess the suitable combinations of sowing dates and planting } \\
\text { distances and their effects on various quantitative and qualitative attributes of okra } \\
\text { at two locations viz., Vegetable Research Farm, I.Ag.Scs., BHU, Varanasi and } \\
\text { Lalganj Village, Mirzapur, Uttar Pradesh during the year } 2015 \text { and 2016. The }\end{array}$ \\
\hline Article Info & and to be the best in relation to most of the growth, flowering \\
\hline $\begin{array}{l}\text { Accepted: } \\
\text { 29 June } 2017 \\
\text { Available Online: } \\
10 \text { July } 2017\end{array}$ & $\begin{array}{l}\text { and quality characteristics, followed by closer spacing }(60 \times 45 \mathrm{~cm}) \text { with } \mathrm{D}_{3}\left(30^{\text {th }}\right. \\
\text { June sowing). Further trials are needed to be conducted before arriving at a } \\
\text { decisive finding and to recommend the appropriate combination to the farmers of } \\
\text { Varanasi, Mirzapur, and adjoining areas. }\end{array}$ \\
\hline
\end{tabular}
\end{abstract}

\section{Introduction}

Okra [Abelmoschus esculentus (L.) Moench] is a quite popular crop due to its easy cultivation, dependable yield adaptability to varying moisture conditions, soil types, and is also tolerant to wide variation in rainfall. Okra has been treated as the staple food in Africa and in Asia as diaspora cuisine for a long time. It is a semi-woody, fibrous, herbaceous annual plant with indeterminate growth habit, but the extent of the fruiting period depends on the combination of the photoperiod sensitivity of the cultivar and day light duration. Okra has originated from Ethiopia in Africa (Khalid et al., 2005) and was first cultivated by Egyptians in the $12^{\text {th }}$ century (Thompson et al., 1979). The plant often reaches 60 to $180 \mathrm{~cm}$ in height and sometimes even up to $4 \mathrm{~m}$.

The leaf is simple (lobed or un-lobed but not separated into leaflets), and its arrangement is alternate. Red pigmentation can occur in stems, petioles, leaf veins, pedicel, petal bases and fruits, which gives the plant ornamental look. Okra has large, attractive hibiscus like flowers which are auxiliary and solitary. Regarding nutritional enrichment, okra is an essential source of carbohydrate, protein, vitamins $\mathrm{A}, \mathrm{B}, \mathrm{C}$, calcium, potassium, dietary fibers, and minerals. Plant spacing less than optimum results in reduced growth, less yield, and poor quality fruits while high plant 
density may lead to vigorous growth, poor quality fruits and low yield due to intra specific competition, (Moniruzzaman et al., 2007). One of the principal aspects of crop production is the adoption of inappropriate plant spacing systems in the field. This either reduces the number of plants per hectare or causes overcrowding, making weeding and other farm operations difficult. Both the cases lead to the yield penalty and ultimately the loss to the growers. Okra must be harvested on a regular basis for better yield returns. If the fruits are allowed to mature on the plant then flowering will be reduced and further fruiting will be hindered. Among the constraints in production of okra, conventional methods such as sowing dates and proper plant spacing are important issues to handle; each and every crop needs a proper sowing date depending upon climatic conditions, soil and variety so that its critical stage should coincide with favorable weather conditions. If a good cultivar is sown at proper time, at a proper location with optimum spacing, it may give maximum yield.

\section{Materials and Methods}

The research work was conducted in two locations i.e., first one on Vegetable Research Farm, Department of Horticulture, Institute of Agricultural Sciences, Banaras Hindu University, Varanasi and the second trial of this research was conducted in Lalganj village of Mirzapur district of Uttar Pradesh during both the years 2015 and 2016. The experimental field was well drained with uniform topography and having assured source of water supply. Harrowing and planking were done before the execution of layout of the experimental field. Proper ploughing was performed in order to bring fine tilth. 27 plots, each of $3 \times 3 \mathrm{~m}^{2}$ size were prepared. The seeds were planted on raised ridges with different sowing dates and planting spacings. About two to three seeds were sown at one place then thinning of seedlings was performed maintaining one plant per stand after germination. Fertilizers were applied as per the recommendation i.e., 100:60:50 kg N, $\mathrm{P}_{2} \mathrm{O}_{5}$, and $\mathrm{K}_{2} \mathrm{O}$. As per the need, the experimental plots were irrigated during the cropping period. Four weedings were practiced as per the requirement with the view to maintain the proper growth of the crop. Five plants from the total population were randomly selected for recording of the observations. The various yield and qualitative parameters taken under study are days to $50 \%$ flowering, node at which first flower appears, days to first fruit setting, fruit length $(\mathrm{cm})$, fruit width $(\mathrm{cm})$, number of fruits per plant, average fruit weight (g), fruit yield per plant $(\mathrm{kg})$, and fruit yield ( $\mathrm{q} / \mathrm{ha})$. The observations recorded were summed up and divided by five to get the mean value. The experiment was laid out in Randomized Complete Block Design with three replications. Three sowing dates i.e., $10^{\text {th }}\left(\mathrm{D}_{1}\right)$, $20^{\text {th }}\left(\mathrm{D}_{2}\right)$, and $30^{\text {th }}$ June $\left(\mathrm{D}_{3}\right)$ at ten days interval and three spacing i.e., $60 \times 45 \mathrm{~cm}$ $\left(\mathrm{S}_{1}\right), 60 \times 60 \mathrm{~cm}\left(\mathrm{~S}_{2}\right)$, and $60 \times 75 \mathrm{~cm}\left(\mathrm{~S}_{3}\right)$ and their combinations were practiced at both the locations. Statistical analysis of data collected was based on the procedure for Randomized Complete Block Design (RCBD) for factorial experiment as outlined by Steel and Torrie (1980).

\section{Results and Discussion}

Significant effect was observed from the findings on planting distances, sowing dates and their interactions depicting their importance on growth, yield, and quality attributes in okra.

During the year 2015 and 2016 at both the locations, for the days to $50 \%$ flowering $\mathrm{S}_{3}$ spacing $(60 \times 75 \mathrm{~cm})$ exhibited minimum number of days to $50 \%$ flowering. In case of 
date of sowing $\mathrm{D}_{3} \quad\left(30^{\text {th }}\right.$ June $)$ sowing exhibited minimum number of days to $50 \%$ flowering in both the year at both the locations. The data pertaining to interaction effect on spacing and sowing dates in the year 2015 at location I and II and in 2016 at location $\mathrm{I}, \mathrm{S}_{3} \mathrm{D}_{3}$ exhibited minimum number of days to $50 \%$ flowering, while in 2016 at location II, $\mathrm{S}_{3} \mathrm{D}_{3}$ exhibited minimum days to $50 \%$ flowering as demonstrated in table 1. Yadav and Dhankhar (1999); Amjad et al., (2001); Rahman et al., (2005), EL-Waraky (2014) and Celline et al., (2015) reported similar result that wider spaced plants recorded early or minimum days to flowering than plant spaced at closer. In respect of sowing dates, the findings of Fondioet al., (2003); Bajpai et al., (2004); Ahmad et al., (2007) and Ekwu and Nwokwu (2012) are in agreement with the present findings.

The data (shown in Table 2) pertaining to the node at which first flower appears reveal that in the year 2015 at location I and 2016 at both the locations, $S_{3}$ spacing $(60 \times 75 \mathrm{~cm})$ produced first flower at lowest number of node, while in the year 2015 at location II the first flower appeared at the lowest number of node in $S_{2}$ spacing $(60 \times 60 \mathrm{~cm})$. In case of date of sowing $\mathrm{D}_{3} \quad\left(30^{\text {th }}\right.$ June $)$ sowing registered the lowest number of node at which first flower appears. The data pertaining to the interaction effect on spacing and sowing dates reveal that, $S_{3} D_{3}$ exhibited the lowest number of node at which first flower appears in the year 2015 at location I and in the year 2016 at both the locations, whereas in 2015 at location II, $S_{2} D_{2}$ and $S_{2} D_{3}$ were at par with equal minimum mean value. Mousa et al., (2007) and Kumar (2015) reported similar results in respect to spacing and dates of sowing.

During the year 2015 and 2016 at both the locations, $S_{3}$ spacing $(60 \times 75 \mathrm{~cm})$ registered the minimum number of days to first fruit setting, whereas in case of sowing dates, in the year 2015 at location I and II, and in the year 2016 at location II, $\mathrm{D}_{3}$ ( $30^{\text {th }}$ June) sowing recorded the minimum number of days to first fruit setting and in the year 2016 at location I, $\mathrm{D}_{2} \quad\left(20^{\text {th }}\right.$ June $)$ registered the minimum number of days to first fruit setting. The interaction effect of spacing and sowing dates reveal that $S_{3} D_{3}$ registered the minimum number of days to first fruit setting among the treatments as illustrated in table 3. Yadav and Dhankar (1999); Bajpai et al., (2004); Paththinige et al., (2008); Singh et al., (2013) and Celline et al., (2015) reported similar results in respect of spacing and sowing dates.

From the table 4 it is clear that in the year 2015 at both the locations and in 2016 at location II, $S_{2}$ spacing $(60 \times 60 \mathrm{~cm})$ registered maximum fruit length, while in 2016 at location I; $S_{1}$ spacing $(60 \times 45 \mathrm{~cm})$ recorded maximum fruit length. In case of sowing dates, $\mathrm{D}_{3} \quad\left(30^{\text {th }}\right.$ June $)$ sowing registered maximum fruit length in both the years and at both the locations. The interaction effect of spacing and sowing dates, in the year 2015 at location I and in 2016 at the same location, the maximum fruit length was found in $\mathrm{S}_{2} \mathrm{D}_{3}$, whereas at location II in the year 2015 and at same location in 2016, $\mathrm{S}_{1} \mathrm{D}_{3}$ produced maximum fruit length. Talukder et al., (2003) and Maurya et al., (2013) reported similar results in respect of spacing and sowing dates.

In both the years 2015 and 2016 at both the locations, $S_{2}$ spacing $(60 \times 60 \mathrm{~cm})$ recorded maximum fruit width, whereas in case of sowing dates $\mathrm{D}_{3} 30^{\text {th }}$ June sowing recorded the maximum fruit width. The result of interaction effect on spacing and sowing dates in the year 2015 at both the locations, $S_{2} D_{2}$ registered maximum fruit width, while in the year 2016 at location $\mathrm{I}, \mathrm{S}_{2} \mathrm{D}_{3}$ produced maximum fruit width, while in the same year at location II, $\mathrm{S}_{1} \mathrm{D}_{3}$ and $\mathrm{S}_{2} \mathrm{D}_{3}$ recorded maximum fruit width (Table 5). The 
maximum fruit width got in intermediate spacing might be as a result of micro-climate or it may be the optimum spacing for growth of okra in the particular location which is in agreement with the finding of El-Waraky (2014).

The data, as illustrated in table 9, pertaining to both the years 2015 and 2016 and both the locations, $S_{1}$ spacing $(60 \times 45 \mathrm{~cm})$ exhibited highest number of fruits per plant, while in case of sowing dates, $\mathrm{S}_{3}\left(30^{\text {th }}\right.$ June) sowing recorded maximum number of fruits per plant. The data pertaining to the interaction effect on spacing and sowing dates in the year 2015 at location $\mathrm{I}, \mathrm{S}_{1} \mathrm{D}_{1}$ exhibited maximum number of fruits per plant, while in the year 2015 at location II and in 2016 at both the locations $\mathrm{S}_{1} \mathrm{D}_{3}$ registered maximum number of fruits per plant. It showed that plant population affected the production of fruits per plant, as the maximum number of fruits was influenced by plant density.

Talukader et al., (2003); Firoz et al., (2007) and Madisa et al., (2015) reported similar results in respect to spacing and dates of sowing. During both the years 2015 and 2016 at both the locations, $S_{2}$ spacing $(60 \times 60 \mathrm{~cm})$ recorded maximum average fruit weight among all the treatments; while in case of sowing dates $\mathrm{D}_{3}$ ( $30^{\text {th }}$ June) sowing registered the maximum average fruit weight. The interaction effect of spacing and sowing dates indicate that $\mathrm{S}_{2} \mathrm{D}_{3}$ registered maximum average fruit weight in the year 2015 at location I and in 2016 at location I and II, while $\mathrm{S}_{2} \mathrm{D}_{2}$ registered the maximum fruit weight in 2015 at location II as demonstrated in table 6. The higher number of plant population lowers the fruit weight of okra, while the low plant population density leads to more fruit weight. Ekwu and Nwokwu (2012) reported similar results in respect to date of sowing.
From the table 7, it is clear that in both the years 2015 and 2016 as well as at over all locations $S_{2}$ spacing $(60 \times 60 \mathrm{~cm})$ registered the maximum fruit yield per plant $(\mathrm{kg})$, while in case of sowing dates $\mathrm{D}_{3}$ ( $30^{\text {th }}$ June) sowing registered the maximum fruit yield per plant. In respect of interaction effect of spacing and sowing dates, $S_{1} D_{3}$ exhibited the highest fruit yield per plant in the year 2015 at location I, while in 2015 at location II and in the year 2016 at both the locations $S_{2} D_{3}$ registered highest fruit yield per plant. These results are in accordance with the findings of Talukdar et al., (2003) and Firoz et al., (2007).

During the years 2015 and 2016 at both the locations, $S_{2}$ spacing $(60 \times 60 \mathrm{~cm})$ exhibited the maximum fruit yield $(\mathrm{q} / \mathrm{ha})$, while in case of sowing dates, $D_{1}\left(10^{\text {th }}\right.$ June $)$ sowing registered maximum fruit yield ( $\mathrm{q} / \mathrm{ha}$ ). The data pertaining to the interaction effect of spacing and sowing dates, in the year 2015 at both the locations and in the year 2016 at location II, $\mathrm{S}_{2} \mathrm{D}_{1}$ registered the maximum fruit yield per plant, while in the year 2016 at location I; $S_{1} D_{1}$ exhibited the highest fruit yield per plant (Table 8). Talukdar et al., (2003) and Paththiniage et al., (2008) reported similar results in respect of spacing, while in case of date of sowing similar findings have been reported by Yogesh et al., (2001) who reported that early sowing gave higher fruit yield than late sowing. Among the different treatments intermediate spacing (60 $\times 60 \mathrm{~cm})$ along with $\mathrm{D}_{3}\left(30^{\text {th }}\right.$ June $)$ sowing found to be superior than the other treatments for most of the yield attributing traits, followed by closer spacing $(60 \times 45 \mathrm{~cm})$ with $\mathrm{D}_{3}$ ( $30^{\text {th }}$ June) sowing. The maximum fruit length $(\mathrm{cm})$ and number of nodes per plant were achieved in closer spacing $(60 \times 45 \mathrm{~cm})$, while fruit width $(\mathrm{cm})$, average fruit weight $(\mathrm{g})$, fruit yield per plant, and fruit yield (q/ha) were attained in intermediate spacing $(60 \times 60$ $\mathrm{cm})$. 
Table.1 Effect of spacing and sowing dates on days to $50 \%$ flowering

\begin{tabular}{|c|c|c|c|c|}
\hline \multirow[b]{2}{*}{ Treatment } & \multicolumn{2}{|c|}{2015} & \multicolumn{2}{|c|}{2016} \\
\hline & Location I & Location II & Location I & Location II \\
\hline \multicolumn{5}{|l|}{ Spacings } \\
\hline $\mathrm{S}_{1}$ & 43.33 & 42.55 & 43.55 & 44.77 \\
\hline $\mathrm{S}_{2}$ & 44.44 & 44.22 & 43.33 & 45.33 \\
\hline $\mathrm{S}_{3}$ & 42.33 & 40.55 & 41.55 & 43.44 \\
\hline S.E. & 0.62 & 0.38 & 0.69 & 0.56 \\
\hline C.D. at $5 \%$ & NS & NS & NS & NS \\
\hline \multicolumn{5}{|l|}{ Sowing dates } \\
\hline $\mathrm{D}_{1}$ & 43.55 & 42.88 & 44.00 & 45.66 \\
\hline $\mathrm{D}_{2}$ & 43.55 & 42.66 & 42.88 & 44.33 \\
\hline $\mathrm{D}_{3}$ & 43.00 & 41.77 & 41.55 & 43.55 \\
\hline S.E. & 0.37 & 0.32 & 0.60 & 0.50 \\
\hline C.D. at $5 \%$ & NS & NS & 1.80 & 1.50 \\
\hline \multicolumn{5}{|c|}{ Interactions (spacing and sowing date) } \\
\hline $\mathrm{S}_{1} \mathrm{D}_{1}$ & 42.33 & 42.66 & 44.33 & 45.66 \\
\hline $\mathrm{S}_{1} \mathrm{D}_{2}$ & 43.66 & 42.66 & 43.33 & 45.00 \\
\hline $\mathrm{S}_{1} \mathrm{D}_{3}$ & 44.00 & 42.33 & 43.00 & 43.66 \\
\hline $\mathrm{S}_{2} \mathrm{D}_{1}$ & 45.33 & 45.33 & 44.66 & 46.33 \\
\hline $\mathrm{S}_{2} \mathrm{D}_{2}$ & 44.33 & 44.33 & 43.66 & 45.66 \\
\hline $\mathrm{S}_{2} \mathrm{D}_{3}$ & 43.66 & 43.00 & 41.66 & 44.00 \\
\hline $\mathrm{S}_{3} \mathrm{D}_{1}$ & 43.00 & 40.66 & 43.00 & 45.00 \\
\hline $\mathrm{SD}_{2}$ & 42.66 & 41.00 & 41.66 & 42.33 \\
\hline $\mathrm{S}_{3} \mathrm{D}_{3}$ & 41.33 & 40.00 & 40.00 & 43.00 \\
\hline S.E. & 0.90 & 0.79 & 1.47 & 1.23 \\
\hline C.D. at $5 \%$ & 1.92 & 1.69 & 3.12 & 2.60 \\
\hline
\end{tabular}


Table.2 Effect of spacing and sowing dates on node at first flower appears

\begin{tabular}{|c|c|c|c|c|}
\hline \multirow[b]{2}{*}{ Treatment } & \multicolumn{2}{|c|}{2015} & \multicolumn{2}{|c|}{2016} \\
\hline & Location I & Location II & Location I & Location II \\
\hline \multicolumn{5}{|l|}{ Spacings } \\
\hline $\mathrm{S}_{1}$ & 6.15 & 6.12 & 6.56 & 6.68 \\
\hline $\mathrm{S}_{2}$ & 5.36 & 5.27 & 5.70 & 5.82 \\
\hline $\mathrm{S}_{3}$ & 5.24 & 5.28 & 5.11 & 5.47 \\
\hline S.E & 0.12 & 0.20 & 0.20 & 0.08 \\
\hline C.D. at $5 \%$ & 0.47 & NS & NS & 0.34 \\
\hline \multicolumn{5}{|l|}{ Sowings dates } \\
\hline $\mathrm{D}_{1}$ & 5.96 & 5.95 & 6.06 & 6.60 \\
\hline $\mathrm{D}_{2}$ & 5.54 & 5.48 & 5.81 & 5.91 \\
\hline $\mathrm{D}_{3}$ & 5.25 & 5.24 & 5.50 & 5.47 \\
\hline S.E. & 0.05 & 0.08 & 0.12 & 0.09 \\
\hline C.D. at $5 \%$ & 0.15 & 0.24 & 0.38 & 0.27 \\
\hline \multicolumn{5}{|c|}{ Interactions (spacing and sowing date) } \\
\hline $\mathrm{S}_{1} \mathrm{D}_{1}$ & 6.56 & 6.66 & 7.13 & 6.96 \\
\hline $\mathrm{S}_{1} \mathrm{D}_{2}$ & 6.16 & 6.10 & 6.40 & 6.76 \\
\hline $\mathrm{S}_{1} \mathrm{D}_{3}$ & 5.73 & 5.60 & 6.16 & 6.33 \\
\hline $\mathrm{S}_{2} \mathrm{D}_{1}$ & 5.80 & 5.76 & 5.93 & 6.56 \\
\hline $\mathrm{S}_{2} \mathrm{D}_{2}$ & 5.26 & 5.03 & 5.86 & 5.83 \\
\hline $\mathrm{S}_{2} \mathrm{D}_{3}$ & 5.03 & 5.03 & 5.30 & 5.06 \\
\hline $\mathrm{S}_{3} \mathrm{D}_{1}$ & 5.53 & 5.43 & 5.13 & 6.26 \\
\hline $\mathrm{S}_{3} \mathrm{D}_{2}$ & 5.20 & 5.33 & 5.16 & 5.13 \\
\hline $\mathrm{S}_{3} \mathrm{D}_{3}$ & 5.00 & 5.10 & 5.03 & 5.03 \\
\hline S.E. & 0.12 & 0.19 & 0.31 & 0.22 \\
\hline C.D. at $5 \%$ & 0.26 & 0.41 & 0.66 & 0.47 \\
\hline
\end{tabular}


Table.3 Effect of spacing and sowing dates on days to first fruit setting

\begin{tabular}{|c|c|c|c|c|}
\hline \multirow[b]{2}{*}{ Treatment } & \multicolumn{2}{|c|}{2015} & \multicolumn{2}{|c|}{2016} \\
\hline & Location I & Location II & Location I & Location II \\
\hline \multicolumn{5}{|l|}{ Spacings } \\
\hline $\mathrm{S}_{1}$ & 45.17 & 44.71 & 47.30 & 45.77 \\
\hline $\mathrm{S}_{2}$ & 46.26 & 45.81 & 45.78 & 45.44 \\
\hline $\mathrm{S}_{3}$ & 44.28 & 41.96 & 44.66 & 44.88 \\
\hline S.E. & 0.44 & 0.99 & 0.57 & 0.56 \\
\hline C.D. at $5 \%$ & NS & NS & 2.248 & NS \\
\hline \multicolumn{5}{|l|}{ Sowing dates } \\
\hline $\mathrm{D}_{1}$ & 45.34 & 44.65 & 46.03 & 46.22 \\
\hline $\mathrm{D}_{2}$ & 45.73 & 44.21 & 45.23 & 45.55 \\
\hline $\mathrm{D}_{3}$ & 44.65 & 43.62 & 46.48 & 44.33 \\
\hline S.E. & 0.32 & 0.45 & 0.24 & 0.36 \\
\hline C.D. at $5 \%$ & NS & NS & 0.746 & 1.103 \\
\hline \multicolumn{5}{|c|}{ Interactions (spacing and sowing date) } \\
\hline $\mathrm{S}_{1} \mathrm{D}_{1}$ & 44.36 & 45.00 & 47.13 & 46.33 \\
\hline $\mathrm{S}_{1} \mathrm{D}_{2}$ & 45.20 & 44.26 & 45.23 & 45.33 \\
\hline $\mathrm{S}_{1} \mathrm{D}_{3}$ & 45.96 & 44.86 & 49.53 & 45.66 \\
\hline $\mathrm{S}_{2} \mathrm{D}_{1}$ & 46.53 & 47.13 & 45.96 & 46.00 \\
\hline $\mathrm{S}_{2} \mathrm{D}_{2}$ & 47.13 & 45.80 & 45.40 & 46.33 \\
\hline $\mathrm{S}_{2} \mathrm{D}_{3}$ & 45.13 & 44.50 & 46.00 & 44.00 \\
\hline $\mathrm{S}_{3} \mathrm{D}_{1}$ & 45.13 & 41.83 & 45.00 & 46.33 \\
\hline $\mathrm{S}_{3} \mathrm{D}_{2}$ & 44.86 & 42.56 & 45.06 & 45.000 \\
\hline $\mathrm{S}_{3} \mathrm{D}_{3}$ & 42.86 & 41.50 & 43.93 & 43.33 \\
\hline S.E & 0.79 & 1.11 & 0.60 & 0.90 \\
\hline C.D. at $5 \%$ & 1.69 & 2.35 & 1.29 & 1.90 \\
\hline
\end{tabular}


Table.4 Effect of spacing and sowing dates on fruit length $(\mathrm{cm})$

\begin{tabular}{|c|c|c|c|c|}
\hline \multirow[b]{2}{*}{ Treatment } & \multicolumn{2}{|c|}{2015} & \multicolumn{2}{|c|}{2016} \\
\hline & Location I & Location II & Location I & Location II \\
\hline \multicolumn{5}{|l|}{ Spacings } \\
\hline $\mathrm{S}_{1}$ & 10.37 & 10.50 & 12.28 & 10.78 \\
\hline $\mathrm{S}_{2}$ & 10.72 & 10.72 & 12.07 & 11.11 \\
\hline $\mathrm{S}_{3}$ & 8.77 & 8.96 & 9.32 & 8.63 \\
\hline S.E. & 0.32 & 0.16 & 0.37 & 0.20 \\
\hline C.D. at $5 \%$ & 1.28 & 0.65 & 1.47 & 0.82 \\
\hline \multicolumn{5}{|l|}{ Sowing dates } \\
\hline $\mathrm{D}_{1}$ & 8.65 & 8.86 & 9.61 & 8.85 \\
\hline $\mathrm{D}_{2}$ & 9.95 & 10.11 & 10.86 & 9.92 \\
\hline $\mathrm{D}_{3}$ & 11.26 & 11.21 & 13.21 & 11.75 \\
\hline S.E. & 0.14 & 0.16 & 0.23 & 0.16 \\
\hline C.D. at $5 \%$ & 0.42 & 0.48 & 0.70 & 0.50 \\
\hline \multicolumn{5}{|c|}{ Interactions (spacing and sowing date) } \\
\hline $\mathrm{S}_{1} \mathrm{D}_{1}$ & 9.10 & 9.13 & 10.66 & 9.36 \\
\hline $\mathrm{S}_{1} \mathrm{D}_{2}$ & 9.86 & 10.03 & 11.73 & 9.80 \\
\hline $\mathrm{S}_{1} \mathrm{D}_{3}$ & 12.16 & 12.33 & 14.46 & 13.20 \\
\hline $\mathrm{S}_{2} \mathrm{D}_{1}$ & 8.93 & 8.76 & 10.20 & 9.06 \\
\hline $\mathrm{S}_{2} \mathrm{D}_{2}$ & 11.00 & 11.30 & 11.33 & 11.26 \\
\hline $\mathrm{S}_{2} \mathrm{D}_{3}$ & 12.23 & 12.10 & 14.70 & 13.00 \\
\hline $\mathrm{S}_{3} \mathrm{D}_{1}$ & 7.93 & 8.70 & 7.96 & 8.13 \\
\hline $\mathrm{S}_{3} \mathrm{D}_{2}$ & 9.00 & 9.00 & 9.53 & 8.70 \\
\hline $\mathrm{S}_{3} \mathrm{D}_{3}$ & 9.40 & 9.20 & 10.46 & 9.06 \\
\hline S.E. & 0.34 & 0.39 & 0.57 & 0.41 \\
\hline C.D. at $5 \%$ & 0.73 & 0.84 & 0.21 & 0.87 \\
\hline
\end{tabular}


Table.5 Effect of spacing and sowing dates on fruit width (cm)

\begin{tabular}{|c|c|c|c|c|}
\hline \multirow[b]{2}{*}{ Treatment } & \multicolumn{2}{|c|}{2015} & \multicolumn{2}{|c|}{2016} \\
\hline & Location I & Location II & Location I & Location II \\
\hline \multicolumn{5}{|l|}{ Spacings } \\
\hline $\mathrm{S}_{1}$ & 1.17 & 1.13 & 1.44 & 1.26 \\
\hline $\mathrm{S}_{2}$ & 1.32 & 1.27 & 1.48 & 1.32 \\
\hline $\mathrm{S}_{3}$ & 1.17 & 1.12 & 1.26 & 1.15 \\
\hline S.E. & 0.04 & 0.03 & 0.01 & 0.04 \\
\hline C.D. at $5 \%$ & NS & 0.131 & 0.076 & NS \\
\hline \multicolumn{5}{|l|}{ Sowing dates } \\
\hline$D_{1}$ & 1.14 & 1.10 & 1.28 & 1.16 \\
\hline $\mathrm{D}_{2}$ & 1.24 & 1.20 & 1.42 & 1.23 \\
\hline $\mathrm{D}_{3}$ & 1.28 & 1.23 & 1.48 & 1.34 \\
\hline S.E. & 0.03 & 0.02 & 0.01 & 0.03 \\
\hline C.D. at $5 \%$ & 0.09 & 0.08 & 0.05 & 0.11 \\
\hline \multicolumn{5}{|c|}{ Interactions (spacing and sowing date) } \\
\hline $\mathrm{S}_{1} \mathrm{D}_{1}$ & 1.10 & 1.03 & 1.33 & 1.16 \\
\hline $\mathrm{S}_{1} \mathrm{D}_{2}$ & 1.13 & 1.13 & 1.46 & 1.23 \\
\hline $\mathrm{S}_{1} \mathrm{D}_{3}$ & 1.30 & 1.23 & 1.53 & 1.40 \\
\hline $\mathrm{S}_{2} \mathrm{D}_{1}$ & 1.26 & 1.20 & 1.36 & 1.23 \\
\hline $\mathrm{S}_{2} \mathrm{D}_{2}$ & 1.36 & 1.33 & 1.50 & 1.33 \\
\hline $\mathrm{S}_{2} \mathrm{D}_{3}$ & 1.33 & 1.30 & 1.60 & 1.40 \\
\hline $\mathrm{S}_{3} \mathrm{D}_{1}$ & 1.06 & 1.06 & 1.16 & 1.10 \\
\hline $\mathrm{S}_{3} \mathrm{D}_{2}$ & 1.23 & 1.13 & 1.30 & 1.13 \\
\hline $\mathrm{S}_{3} \mathrm{D}_{3}$ & 1.23 & 1.16 & 1.33 & 1.23 \\
\hline S.E. & 0.07 & 0.07 & 0.04 & 0.09 \\
\hline C.D. at $5 \%$ & 0.15 & 0.14 & 0.09 & 0.19 \\
\hline
\end{tabular}


Table.6 Effect of spacing and sowing dates on average fruit weight (g)

\begin{tabular}{|c|c|c|c|c|}
\hline \multirow[b]{2}{*}{ Treatment } & \multicolumn{2}{|c|}{2015} & \multicolumn{2}{|c|}{2016} \\
\hline & Location I & Location II & Location I & Location II \\
\hline \multicolumn{5}{|l|}{ Spacings } \\
\hline $\mathrm{S}_{1}$ & 10.81 & 10.52 & 11.10 & 10.87 \\
\hline $\mathrm{S}_{2}$ & 12.66 & 12.76 & 13.02 & 12.72 \\
\hline $\mathrm{S}_{3}$ & 11.41 & 11.14 & 11.53 & 8.91 \\
\hline S.E. & 0.25 & 0.37 & 0.22 & 0.37 \\
\hline C.D. at $5 \%$ & 1.00 & 1.46 & 0.88 & 1.45 \\
\hline \multicolumn{5}{|l|}{ Sowing Dates } \\
\hline $\mathrm{D}_{1}$ & 10.34 & 10.21 & 10.67 & 9.84 \\
\hline $\mathrm{D}_{2}$ & 11.91 & 12.04 & 12.08 & 10.83 \\
\hline $\mathrm{D}_{3}$ & 12.63 & 12.17 & 12.88 & 11.83 \\
\hline S.E. & 0.33 & 0.32 & 0.32 & 0.23 \\
\hline C.D. at $5 \%$ & 1.00 & 0.98 & 0.98 & 0.70 \\
\hline \multicolumn{5}{|c|}{ Interactions (spacing and sowing dates) } \\
\hline $\mathrm{S}_{1} \mathrm{D}_{1}$ & 9.06 & 8.93 & 9.20 & 9.56 \\
\hline $\mathrm{S}_{1} \mathrm{D}_{2}$ & 11.40 & 10.70 & 12.03 & 10.96 \\
\hline $\mathrm{S}_{1} \mathrm{D}_{3}$ & 11.96 & 11.9 & 12.06 & 12.10 \\
\hline $\mathrm{S}_{2} \mathrm{D}_{1}$ & 11.30 & 11.06 & 11.80 & 12.16 \\
\hline $\mathrm{S}_{2} \mathrm{D}_{2}$ & 12.73 & 14.10 & 13.06 & 12.53 \\
\hline $\mathrm{S}_{2} \mathrm{D}_{3}$ & 13.96 & 13.13 & 14.20 & 13.46 \\
\hline $\mathrm{S}_{3} \mathrm{D}_{1}$ & 10.66 & 10.63 & 11.03 & 7.80 \\
\hline $\mathrm{S}_{3} \mathrm{D}_{2}$ & 11.60 & 11.33 & 11.16 & 9.00 \\
\hline $\mathrm{S}_{3} \mathrm{D}_{3}$ & 11.96 & 11.46 & 12.40 & 9.93 \\
\hline S.E. & 0.82 & 0.80 & 0.80 & 0.57 \\
\hline C.D. at $5 \%$ & 1.74 & 1.70 & 1.70 & 1.22 \\
\hline
\end{tabular}


Table.7 Effect of spacing and sowing dates on fruit yield per plant $(\mathrm{kg})$

\begin{tabular}{|c|c|c|c|c|}
\hline \multirow{2}{*}{ Treatment } & \multicolumn{2}{|c|}{2015} & \multicolumn{2}{|c|}{2016} \\
\hline & Location I & Location II & Location I & Location II \\
\hline \multicolumn{5}{|l|}{ Spacings } \\
\hline $\mathrm{S}_{1}$ & 147.56 & 147.20 & 158.44 & 153.34 \\
\hline $\mathrm{S}_{2}$ & 159.20 & 156.06 & 162.43 & 156.72 \\
\hline $\mathrm{S}_{3}$ & 121.48 & 120.44 & 122.72 & 119.25 \\
\hline S.E. & 2.83 & 1.98 & 2.40 & 3.12 \\
\hline C.D. at $5 \%$ & 11.13 & 7.79 & 9.43 & 12.27 \\
\hline \multicolumn{5}{|l|}{ Sowing dates } \\
\hline $\mathrm{D}_{1}$ & 129.35 & 122.11 & 134.61 & 126.45 \\
\hline $\mathrm{D}_{2}$ & 138.88 & 136.67 & 143.84 & 140.82 \\
\hline $\mathrm{D}_{3}$ & 160.01 & 159.92 & 165.14 & 162.02 \\
\hline S.E. & 1.62 & 1.69 & 2.08 & 1.81 \\
\hline C.D. at $5 \%$ & 4.85 & 5.06 & 6.25 & 5.43 \\
\hline \multicolumn{5}{|c|}{ Interactions (spacing and sowing date) } \\
\hline $\mathrm{S}_{1} \mathrm{D}_{1}$ & 135.66 & 133.10 & 145.30 & 135.26 \\
\hline $\mathrm{S}_{1} \mathrm{D}_{2}$ & 137.13 & 135.10 & 154.76 & 147.43 \\
\hline $\mathrm{S}_{1} \mathrm{D}_{3}$ & 169.90 & 173.40 & 175.26 & 177.33 \\
\hline $\mathrm{S}_{2} \mathrm{D}_{1}$ & 139.26 & 136.13 & 142.63 & 137.73 \\
\hline $\mathrm{S}_{2} \mathrm{D}_{2}$ & 160.03 & 157.10 & 162.43 & 152.10 \\
\hline $\mathrm{S}_{2} \mathrm{D}_{3}$ & 178.30 & 174.96 & 182.23 & 180.33 \\
\hline $\mathrm{S}_{3} \mathrm{D}_{1}$ & 113.13 & 112.10 & 115.90 & 106.36 \\
\hline $\mathrm{S}_{3} \mathrm{D}_{2}$ & 119.50 & 117.83 & 114.33 & 123.00 \\
\hline $\mathrm{S}_{3} \mathrm{D}_{3}$ & 131.83 & 131.40 & 137.93 & 128.40 \\
\hline S.E. & 3.96 & 4.14 & 5.10 & 4.44 \\
\hline C.D. at $5 \%$ & 8.41 & 8.77 & 10.82 & 9.41 \\
\hline
\end{tabular}


Table.8 Effect of spacing and sowing dates on fruit yield (q/ha)

\begin{tabular}{|c|c|c|c|c|}
\hline \multirow{2}{*}{ Treatment } & \multicolumn{2}{|c|}{2015} & \multicolumn{2}{|c|}{2016} \\
\hline & Location I & Location II & Location I & Location II \\
\hline \multicolumn{5}{|l|}{ Spacings } \\
\hline $\mathrm{S}_{1}$ & 41.56 & 41.26 & 44.66 & 43.14 \\
\hline $\mathrm{S}_{2}$ & 44.66 & 43.76 & 46.11 & 43.91 \\
\hline $\mathrm{S}_{3}$ & 34.36 & 34.08 & 35.97 & 33.60 \\
\hline S.E. & 0.70 & 0.64 & 0.71 & 0.78 \\
\hline C.D. at $5 \%$ & 2.77 & 2.52 & 2.81 & 3.07 \\
\hline \multicolumn{5}{|l|}{ Sowing dates } \\
\hline $\mathrm{D}_{1}$ & 47.84 & 47.04 & 49.88 & 47.00 \\
\hline $\mathrm{D}_{2}$ & 37.53 & 36.90 & 40.50 & 38.02 \\
\hline $\mathrm{D}_{3}$ & 35.22 & 35.17 & 36.36 & 35.63 \\
\hline S.E. & 0.45 & 0.49 & 0.90 & 0.50 \\
\hline C.D. at $5 \%$ & 1.35 & 1.47 & 2.72 & 1.52 \\
\hline \multicolumn{5}{|c|}{ Interactions (spacing and sowing date) } \\
\hline $\mathrm{S}_{1} \mathrm{D}_{1}$ & 50.16 & 49.20 & 53.60 & 50.66 \\
\hline $\mathrm{S}_{1} \mathrm{D}_{2}$ & 37.13 & 36.46 & 41.76 & 39.76 \\
\hline $\mathrm{S}_{1} \mathrm{D}_{3}$ & 37.40 & 38.13 & 38.63 & 39.00 \\
\hline $\mathrm{S}_{2} \mathrm{D}_{1}$ & 51.53 & 50.36 & 52.70 & 51.00 \\
\hline $\mathrm{S}_{2} \mathrm{D}_{2}$ & 43.20 & 42.43 & 45.53 & 41.06 \\
\hline $\mathrm{S}_{2} \mathrm{D}_{3}$ & 39.26 & 38.50 & 40.10 & 39.66 \\
\hline $\mathrm{S}_{3} \mathrm{D}_{1}$ & 41.83 & 41.56 & 43.36 & 39.33 \\
\hline $\mathrm{S}_{3} \mathrm{D}_{2}$ & 32.26 & 31.80 & 34.20 & 33.23 \\
\hline $\mathrm{S}_{3} \mathrm{D}_{3}$ & 29.00 & 28.90 & 30.36 & 28.23 \\
\hline S.E. & 1.11 & 1.20 & 1.22 & 1.24 \\
\hline C.D. at $5 \%$ & 2.35 & 2.55 & 4.71 & 2.63 \\
\hline
\end{tabular}


Table.9 Effect of spacing and sowing dates on number of fruits per plant

\begin{tabular}{|c|c|c|c|c|}
\hline \multirow[b]{2}{*}{ Treatment } & \multicolumn{2}{|c|}{2015} & \multicolumn{2}{|c|}{2016} \\
\hline & Location I & Location II & Location I & Location II \\
\hline \multicolumn{5}{|l|}{ Spacings } \\
\hline $\mathrm{S}_{1}$ & 13.80 & 14.74 & 15.75 & 14.15 \\
\hline $\mathrm{S}_{2}$ & 12.44 & 13.00 & 12.92 & 12.33 \\
\hline $\mathrm{S}_{3}$ & 10.78 & 11.17 & 11.70 & 13.33 \\
\hline S.E. & 0.26 & 0.28 & 0.31 & 0.34 \\
\hline C.D. at 5\% & 1.03 & 1.09 & NS & $\mathrm{NS}$ \\
\hline \multicolumn{5}{|l|}{ Sowing dates } \\
\hline $\mathrm{D}_{1}$ & 12.68 & 12.63 & 13.96 & 13.03 \\
\hline $\mathrm{D}_{2}$ & 11.58 & 12.10 & 12.58 & 13.11 \\
\hline $\mathrm{D}_{3}$ & 12.75 & 14.18 & 14.82 & 13.67 \\
\hline S.E. & 0.34 & 0.29 & 0.35 & 0.25 \\
\hline C.D. at $5 \%$ & 1.02 & 0.87 & $\mathrm{NS}$ & $\mathrm{NS}$ \\
\hline \multicolumn{5}{|c|}{ Interactions (spacing and sowing date) } \\
\hline $\mathrm{S}_{1} \mathrm{D}_{1}$ & 15.00 & 14.90 & 16.36 & 14.33 \\
\hline $\mathrm{S}_{1} \mathrm{D}_{2}$ & 12.13 & 13.90 & 13.96 & 13.46 \\
\hline $\mathrm{S}_{1} \mathrm{D}_{3}$ & 14.27 & 15.43 & 17.93 & 14.66 \\
\hline $\mathrm{S}_{2} \mathrm{D}_{1}$ & 12.37 & 12.36 & 12.96 & 11.43 \\
\hline $\mathrm{S}_{2} \mathrm{D}_{2}$ & 12.20 & 11.83 & 12.60 & 12.16 \\
\hline $\mathrm{S}_{2} \mathrm{D}_{3}$ & 12.76 & 14.80 & 13.20 & 13.40 \\
\hline $\mathrm{S}_{3} \mathrm{D}_{1}$ & 10.70 & 10.63 & 12.56 & 13.33 \\
\hline $\mathrm{S}_{3} \mathrm{D}_{2}$ & 10.43 & 10.56 & 11.20 & 13.70 \\
\hline $\mathrm{S}_{3} \mathrm{D}_{3}$ & 11.23 & 12.33 & 11.33 & 12.96 \\
\hline S.E. & 0.83 & 0.71 & 0.91 & 0.61 \\
\hline C.D. at 5\% & 1.77 & 1.50 & 1.96 & 1.30 \\
\hline
\end{tabular}

Considering the days to $50 \%$ flowering, node at which first flower appears, days to first fruit setting, fruit length $(\mathrm{cm})$, fruit width (cm), number of fruits per plant, average fruit weight $(\mathrm{g})$, and fruit yield per plant. Based on these findings, okra seeds sown on $\mathrm{D}_{3}\left(30^{\text {th }}\right.$ June) with intermediate spacing $(60 \times 60 \mathrm{~cm})$ is therefore can be recommended for the farmers of Varanasi district and adjoining areas after conduction of more necessitating trials at various locations.

\section{References}

Ahmed, A.A. 2007. Effect of sowing date on seed yield and quality of two okra (Abelmoschusesculentus L. Moench) cultivars, Thesis, M.Sc. Sudan University of Science and Technology, Sudan. 77p.

Amjad, M., Anjum, M.A. and Ali, A. 2001. Effect of phosphorus and planting density on seed production in okra (Abelmoschusesculentus L. Moench. J. Agri. Biol., 3(4): 380-383.
Bajpai, V.P., Khan, A.A., Kumar, S., Singh, P. and Singh, C.B. 2004. Effect of spacing and sowing dates on growth and seed quality of okra [Abelmoschusesculentus (L.) Moench.]. Farm Sci. J., 13(2): 116117.

Celline, H.A., Bake, I.D. and Futuless, K.N. 2015. Effects of weeding regime and inter-row spacing on the growth and pod yield of okra [Abelmoschusesculentus (L.) Moench].Adamawa State University J. Agri. Sci., 13: 95-100.

Ekwu, L.G. and Nwokwu, G.N. 2012. Effect of plant spacing and planting date on the growth and yield of okra (Abelmoschusesculentus L.) in Abakaliki. Int. J. Agri. Rural Develop., 15(2): 10411048.

El-Waraky, Y.B. 2014. Effect of sowing date, plant density and phosphorus fertilization on seed yield of okra. Alexandria J. Agri. Res., 59(1): 27-41.

Firoz, Z.A., Islam, M.A., Mohiuddin, M. and Rahman, M.M. 2007. Yield and yield attributes of okra as influenced by 
planting time and plant spacing in hill slope condition. Progressive Agric., 18(2): 67-73.

Fondio, L., Djidji, H.A., Kouame, C. and Traore, D. 2003. Effect of sowing date on the production of okra (Abelmoschusesculentus L. Moench) in Central Ivory Coast. Agronomie Africaine, 15(1): 13-27.

Khalid, U., Ahmed, E. and Muhammad, U.K. 2005. Integrated weed management in okra. Pak. Weed Sci. J., 11(1/2): 55-60.

Kumar, V. 2015. Effect of spacing and fertilizers on growth, yield and seed quality of okra.Thesis, M.Sc. Chaudhary Charan Singh Haryana Agricultural University, Hisar. 95p

Madisa, M.E., Mathowal, T., Mpofu1, C. and Oganne, T.A. 2015. Effects of plant spacing on the growth, yield and yield components of okra (Abelmoschusesculentus L.) in Botswana. American J. Experimental Agri., 6(1): 714.

Maurya, R.P., Bailey, J.A., and Chandler, J.S.A. 2013. Impact of plant spacing and picking interval on the growth, fruit quality and yield of okra [Abelmoschusesculentus (L.) Moench]. American J. Agri. Forestry, 1(4): 48-54.

Moniruzzaman, M., Uddin, M.Z. and Choudhury, A.K. 2007. Response of okra seed crop to sowing time and plant spacing in south eastern hilly region of Bangladesh. Bangladesh J. Agri. Res., 32(3): 393-402.

Mousa, M.A.A., Mohamed, F., Dokashi, M.H. and Elnobi, E.E.F.E. 2007. Intra row intercropping of cowpea and cucumber with okra as influenced by planting date of secondary crops. Assiut University Bull. Environ. Res., 10(1): 13-34.

Paththinige, S.S., Upashantha, P.S.G., Ranaweera, B.R.M. and Fonseka, R.M. 2008. Effect of plant spacing on yield and fruit characteristics of okra (Abelmoschusesculentus), Trop. Agri. Res., 20: 336-342.

Rahman, M.A. 2005. Effect of spacing and different levels of nitrogen on the growth and yield of okra. Thesis, M.Sc.(Horti. Bangladesh Agriculture University, Mymensingh. 77p.

Singh, S., Rajbeer, J.R. and Kaushtk, N.H. 2013. Effect of sowing dates and plant geometry on growth and yield of okra cv. ParbhaniKranti and Pusa A-4. Asian J. Horticulture, 8(2): 772-774.

Steel, R.G.D. and Torrie, J.H., 1980. Principles and Procedures of Statistics, McGrawHill, Kogakusha, Tokyo, 633 pp.

Talukder, M.A.H., Mannaf, M.A., Alam, M.K., Salam, M.A. and Amin, M. M. U. 2003. Influence of sowing time, plant spacing and picking interval on the growth and yield of okra. Pak. J. Biol. Sci., 6(18): 1626-1630.

Thompson, H.C. and Kelly, W.C. 1979. Vegetables Crops.New York, McGraw Hill, 562p.

Yadav, S.K. and Dhankhar, B.S. 1999. Performance of VarshaUphar cultivar of okra [Abelmoschusesculentus (L.) Moench] as affected by the sowing dates and plant geometry. Veg. Sci., 26(2): 180182.

\section{How to cite this article:}

Bake, I.D., B.K. Singh, A.K. Singh, D.P. Moharana and Maurya, A.K. 2017. Impact of Planting Distances and Sowing Dates on Yield Attributing Traits of Okra [Abelmoschus esculentus (L.) Moench] cv. Kashi Pragati. Int.J.Curr.Microbiol.App.Sci. 6(7): 4112-4125. doi: https://doi.org/10.20546/ijcmas.2017.607.426 